\title{
Sikap Mengontrol diri dalam menurunkan Kecenderungan Berperilaku Agresif Pada Remaja
}

\author{
Lailatul Badriyah*
}

\begin{abstract}
This research was done to get a mindset controlling in changing the tendency of agretivity teenegers. Variable was used to involving self controlling such as behavior control, cognitive control, and decisional control. The number of sample as much as 150 students that taken by using probability sampling technique. In resulting of validity research, the researcher did modification model of agretivity construction. CFA (Confirmatory Factor Analysis) was used to test a measuring tools and Multiple Regression Analysis was used to test the research hypothesis. All of techniques, the researcher used software SPSS 18.0 and LISREL 8.70. the finding of result shown the three social control aspect named (behavior dan decisional). The evidence of giving the influenced to changing the degree of agresive to teenegers. behavior control $(\mathrm{p}$-value $<0,05)(\mathrm{B}=-0,287)$ Aspect in suppoting the value $8,4 \%$ while decisional control ( $p$-value $<0,05)(B=-0,242)$ in supporting the value $3,1 \%$. Validity test shown fit model by Chi-Square $=322,83 d f=289$ P-Values $=0,08328$ RMSEA $=0,028$.
\end{abstract}

Keyword: self controlling, agretivity

\section{Pendahuluan}

Survei yang dilakukan Komisi pernah mengalami tindakan cyber Perlindungan Anak Indonesia (KPAI) sejak bullying.

tahun 2011 hingga 2017 mencatat adanya

Konsep dalam psikologi sekitar 253 kasus bullying, terdiri dari 122 anak yang menjadi korban dan 131 anak menjadi pelaku. Tidak hanya itu, data lain dari Kementerian Sosial mencatat pula hingga Juni 2017, telah menerima laporan sebanyak 967 kasus; 117 kasus di antaranya adalah kasus bullying. Suatu hal yang mengejutkan bahwasanya kasus yang tengah menjadi sorotan ini didominasi oleh kalangan remaja. Berdasarkan data UNICEF pada tahun 2016, sebanyak 41 hingga 50 persen remaja di Indonesia dalam rentang usia 13 sampai 15 tahun perkembangan, remaja mengalami pergantian moralitas dari konsep-konsep moral khusus ke konsep moral individual. ${ }^{2}$ Selama berada dalam keadaan tersebut, remaja mengalami ambiguitas dalam pola pemikiran kognitif dan afektif sebagai pengarah kepada perilaku yang akan ditampilkan. Salah satu contoh ambiguitas yang dialami remaja adalah mencari identitas diri. Menurut teori Psikososial Erikson, remaja berada di tahap 5 yaitu identity vs identify confusion (identitas vs kebingungan identitas), menurut erikson jika remaja menerima dukungan sosial

*Penulis adalah Dosen Jurusan Dakwah IAIN Bengkulu 
yang memadai, maka akan muncul eksplorasi personal, kepekaan diri, ${ }^{1}$ perasaan mandiri, dan kontrol diri. ${ }^{3}$ Begitu juga sebaliknya remaja yang tidak yakin terhadap kepercayaan diri dan hasratnya ditambah lagi kalau remaja sering kali mendapatkan penolakan dari orang tua, maka dapat dipastikan remaja akan terus mengalami kebingungan. Kebingungankebingungan inilah yang berimbas pada ketidak stabilan emosi. Menurut Carr emosi itu timbul jika organism dihadapkan pada rintangan yang menghambat kebebasannya untuk bergerak, sehingga semua tenaga dan upaya dikerahkan untuk mengatasi rintangan tersebut dan merangsang organism tersebut untuk merugikan lawannya tanpa pertimbangan terlebih dahulu. $^{4}$

Menurut Baron, menyatakan bahwa " Aggression is any form of behavior directed toward the goal of harming or injuring another living being who is motivated to avoid such treatment." Menurut definisi tersebut menyatakan bahwa agresi adalah setiap bentuk perilaku yang diarahkan pada tujuan merugikan atau melukai makhluk hidup yang termotivasi untuk menghindari perlakuan tersebut." 5

Sigmund Freud mengemukakan bahwa perilaku agresi merupakan gambaran ekspresi sangat kuat dari insting kematian (thanatos), karena dengan melakukan agresi maka secara mekanisme individu telah berhasil mengeluarkan energi destruktifnya dalam rangka menstabilkan keseimbangan mental antara insting mencintai (eros) dan insting kematian $\left(\right.$ thanatos $^{6}$. Meski demikian, walaupun agresi dapat dikontrol tetapi agresi tidak bisa dieliminasi, karena agresi adalah sifat alamiah manusia. Myers menjelaskan bahwa agresi merupakan perilaku fisik maupun verbal yang disengaja maupun tidak disengaja namun memiliki maksud untuk menyakiti, menghancurkan atau merugikan orang lain yang diniatkan untuk melukai objek yang menjadi sasaran agresi. $^{7}$ Dan secara spesifik, Gelles dkk mendefinisikan agresi verbal adalah komunikasi yang dimaksudkan untuk menyebabkan penderitaan psikologi kepada orang lain baik secara langsung maupun tidak langsung. ${ }^{8}$

Berbagai teori agresi mengemukakan sebenarnya, agresi itu bukan hanya masalah kekerasan fisik seperti bulliying semata, tetapi banyak perilaku agresi yang dimulai dari agresi yang berupa perkataan (verbal), ataupun olok-olokan yang dirasa menyakitkan individu dan berakhir pada tindakan agresi fisik berupa pemukulan, penusukan, dan lain-lain yang berujung pada tindakan kriminalitas. Setidaknya 
perilaku agresi ini dibagi dalam tiga klasifikasi yaitu, 1) fisik dan verbal, 2) aktif dan pasif, 3) langsung dan tidak langsung. Dari ketiga klasifikasi tersebut akhirnya ditarik delapan bentuk agresif yaitu, 1) Perilaku agresif fisik aktif yang dilakukan secara langsung, misalnya menusuk, menembak, memukul orang lain. 2) Perilaku agresif fisik aktif yang dilakukan secara tidak langsung, misalnya membuat jebakan untuk orang lain. 3) Perilaku agresif fisik pasif yang dilakukan secara langsung, misalnya tidak memberi jalan kepada orang lain. 4) Perilaku agresif fisik pasif yang dilakukan secara tidak langsung, misalnya menolak untuk mengerjakan sesuatu, menolak untuk mengerjakan perintah orang lain. 5) Perilaku agresif verbal aktif yang dilakukan secara langsung, misalnya memaki-maki orang. 6) Perilaku agresif verbal aktif yang dilakukan secara tidak langsung, misalnya menyebar gosip tentang orang lain. 7) Perilaku agresif verbal pasif yang dilakukan secara langsung, misalnya tidak setuju dengan pendapat orang lain, tetapi tidak mau mengatakan (memboikot), tidak mau menjawab pertanyaan orang lain. 8) Perilaku agresif verbal pasif yang dilakukan secara tidak langsung, misalnya menolak untuk berbicara dengan orang lain, menolak memberikan perhatian dalam suatu pembicaraan.
Teori lainnya mengenai agresi, menurut para peneliti W.R. Hess., J. Olds., R.G. Heath., J.M.R. Delgado., et all bahwa agresi dikendalikan oleh wilayah-wilayah saraf di dalam otak. Reaksi efektif terhadap kemarahan dan pola perilaku agresif diaktifkan melalui stimulasi listrik pada amigdala (bagian dari otak kecil), hipotaliamia samping, beberapa bagian dari mesensefalon (otak tengah). Hal ini menunjukkan bahwa agresi bukan hanya sekedar internal motif seperti yang kemukakan oleh Freud, akan tetapi komponen sistem saraf untuk menekan impuls kemarahan yang distimulasi oleh kondisi lingkungan. ${ }^{9}$

Pendapat lain dari Buss dan Perry, bentuk-bentuk agresi itu yaitu agresi fisik, verbal, kemarahan (anger) dan kecurigaan (hostility). Agresi fisik dan verbal dapat dikontrol dengan kemampuan mengontrol perilaku, sehingga individu dapat mengontrol dirinya dengan baik dan mengatur perilaku dengan kemampuan dirinya. Kemarahan dapat dikontrol dengan kemampuan mengantisipasi peristiwa, mengantisipasi keadaan dengan pertimbangan secara objektif. Sedangkan kecurigaan dapat dikontrol dengan menafsirkan peristiwa, karena kemampuan ini menilai dan menafsirkan peristiwa dengan memperhatikan segi-segi positif secara subjetif. ${ }^{10}$ 
Menurut Schmeichel dan Baumeister, kontrol diri mengacu pada sumber daya internal yang tersedia untuk menghambat, menimpa, atau mengubah tanggapan yang mungkin timbul sebagai akibat dari proses fisiologis, kebiasaan, pembelajaran, atau situasi. ${ }^{11}$. Chaplin juga mendefinisikan Self control adalah kemampuan untuk membimbing tingkah laku sendiri, kemampuan untuk menekan atau merintangi impuls-impuls atau tingkah laku impulsif. $^{12}$

Menurut Rothbaum menyatakan bahwa "Self-control is widely regarded as a capacity to change and adapt the self so as to produce a better, more optimal fit between self and world." Maksud dari pernyataan tersebut adalah kontrol diri secara luas dianggap sebagai kapasitas untuk berubah dan beradaptasi dengan diri sehingga menghasilkan sesuatu lebih baik secara optimal antara diri dan dunia." Menurut Tangney, dkk menyatakan bahwa " Central to our concept of self control is the ability to override or change one's inner responses, as well as to interrupt undesired behavioral tendencies and refrain from acting on them." Pernyataan tersebut menyatakan bahwa pusat dari konsep pengendalian diri kita adalah kemampuan untuk mengesampingkan atau mengubah tanggapan batin seseorang, serta untuk menekan kecenderungan perilaku yang tidak diinginkan dan menahan diri dari tindakan tersebut."13

Averill mengemukakan 3 konsep kontrol diri dalam berbagai aspeknya, antara lain sebagai berikut: ${ }^{14}$

- Behavior control (Mengontrol perilaku) Merupakan suatu tindakan langsung terhadap lingkungan. Aspek ini terdiri dari 2 komponen, yaitu: mengatur pelaksanaan (regulated administration), dan memodifikasi stimulus (stimulus modifiability).

- Cognitive Control (Mengontrol Kognisi) Merupakan kemampuan individu untuk mengolah informasi yang tidak diinginkan dengan cara menginterpretasikan, menilai, atau menggabungkan suatu kejadian dalam suatu kerangka kognitif sebagai adaptasi psikologi untuk mengurangi tekanan. Aspek ini terdiri dari 2 komponen, yaitu: memperoleh informasi (information gain) dan melakukan penilaian (apparsial).

- Decisional control (Mengontrol Keputusan) Kemampuan untuk memilih hasil yang diyakini individu, dalam menentukan pilihan akan berfungsi baik dengan adanya suatu kesempatan, kebebasan, atau kemungkinan pada diri individu untuk memilih kemungkinan tindakan. Aspek ini terdiri dari 2 
komponen juga, yaitu: mengantisipasi

peristiwa dan menafsirkan peristiwa, dimana individu dapat menahan dirinya.

Secara teori, terjadinya tindakan agresif karena seseorang tidak bisa mengendalikan emosi yang ada dalam dirinya, sikap agresif yang dipicu karena rasa marah dan dendam akan sangat mudah muncul. Hal ini didukung oleh penelitian Finkenauer,dkk yang menyatakan bahwa tinggi self-control sangat berhubungan dengan penurunan resiko masalah psikososial diantaranya kenakalan dan sikap agresivitas pada remaja. ${ }^{15}$ Dalam penelitian lainnya dari DeWall, dkk tentang Self Control Inhibits Aggression menyatakan bahwa mekanisme neural otak dalam meregulasi emosi dan kontrol kognitif pada self-control dapat mengurangi agresi seseorang. ${ }^{16}$

\section{Metode}

Penelitian ini menggunakan pendekatan kuantitatif dengan Teknik Pengambilan Sampel menggunakan probability sampling, teknik dimana peluang dipilihnya sampel diketahui. Jumlah sampel sebanyak 150 siswa. Teknik pengumpulan data dilakukan dengan menggunakan metode skala likert yaitu dengan menyebarkan angket. Untuk alat ukur agresivitas, peneliti menggunakan skala agresivitas Buss dan Perry (1992) sebanyak 27 item, dan skala pengukuran self-control menggunakan teori Averill (1973) sebanyak 20 item.

Adapun blue print dari instrumen yang digunakan adalah sebagai berikut:

Tabel 1

(Blue Print Instrumen Agresivitas)

\begin{tabular}{|c|c|c|c|c|}
\hline \multirow[t]{2}{*}{ Aspek } & \multirow[t]{2}{*}{ Indikator } & \multicolumn{2}{|c|}{ Nomor item } & \multirow[t]{2}{*}{ Jumlah Item } \\
\hline & & Favorabel & Unfavorabel & \\
\hline Fisik & $\begin{array}{l}\text { - Menyerang } \\
\text { - Memukul }\end{array}$ & 5 & 4 & 9 \\
\hline Verbal & $\begin{array}{l}\text { - Berdebat } \\
\text { - Menyebarkan } \\
\text { gosip } \\
\text { - Bersikap } \\
\text { sarkastis }\end{array}$ & 3 & 2 & 5 \\
\hline Marah & $\begin{array}{l}\text { - Kesal } \\
\text { - Mudah marah }\end{array}$ & 4 & 3 & 7 \\
\hline Permusuhan & $\begin{array}{l}\text { - Benci } \\
\text { - Curiga }\end{array}$ & 5 & 3 & 8 \\
\hline
\end{tabular}


Tabel 2

(Blue Print Instrumen Kontrol Diri)

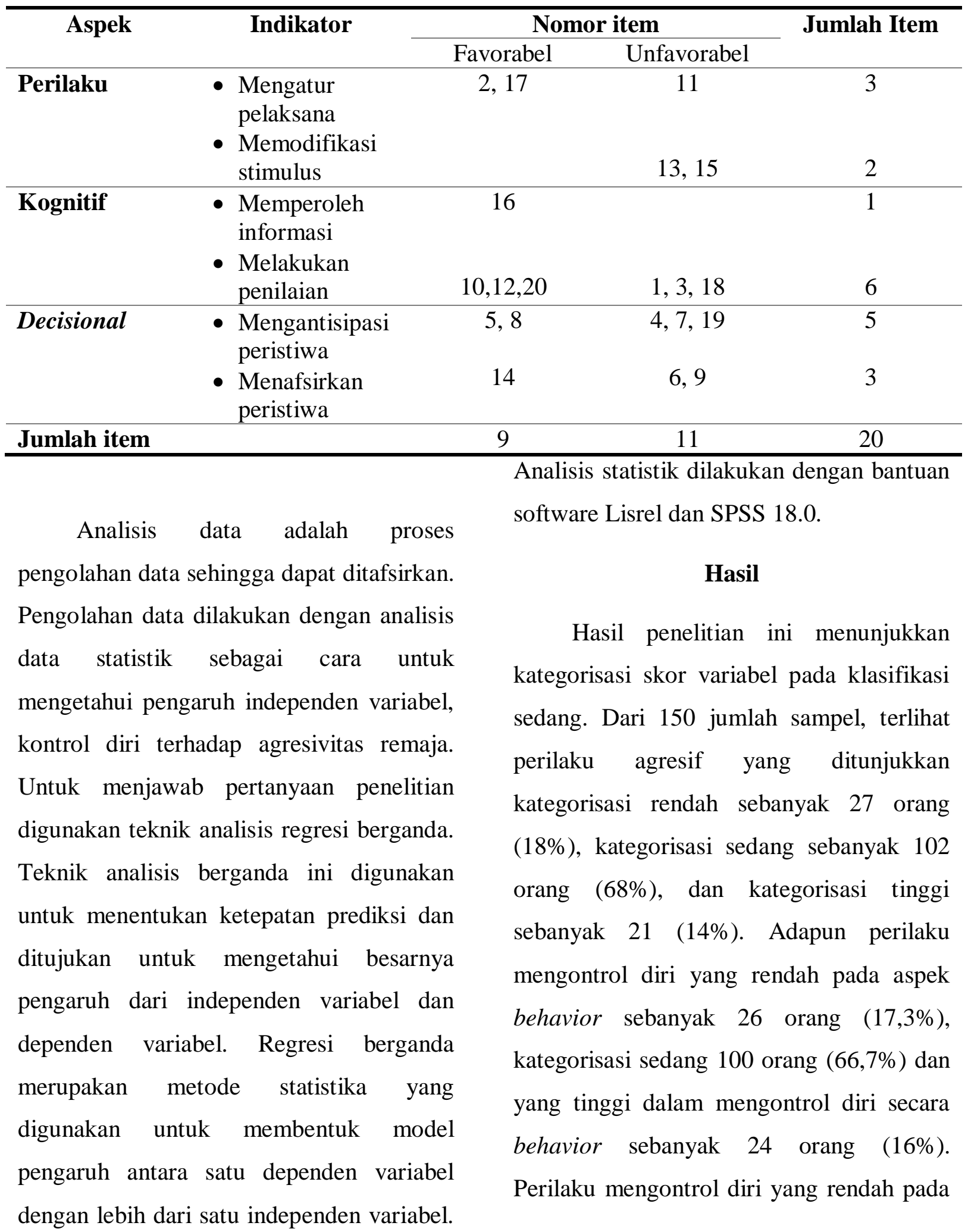


aspek kognitif sebanyak 28 orang $(18,7 \%)$, kategorisasi sedang 95 orang $(63,3 \%)$ dan yang tinggi dalam mengontrol diri secara kognitif sebanyak 27 orang (18\%). Perilaku mengontrol diri yang rendah pada aspek decisional sebanyak 27 orang (18\%), kategorisasi sedang 94 orang $(62,7 \%)$ dan yang tinggi dalam mengontrol diri secara decisional sebanyak 29 orang (19,3\%).

Adapun tabel kategorisasi skor dapat dilihat sebagai berikut:

Tabel 3

Akumulasi Kategorisasi Skor

\begin{tabular}{l|ccc}
\hline \multicolumn{1}{c}{ Variabel } & Rendah $n(\%)$ & Sedang $n(\%)$ & Tinggi $(\%)$ \\
\hline $\begin{array}{l}\text { Agresivitas } \\
\text { Kontrol diri }\end{array}$ & $27(18 \%)$ & $102(68 \%)$ & $21(14 \%)$ \\
- Behavior & $26(17,3 \%)$ & $100(66,7 \%)$ & $24(16 \%)$ \\
- Kognitif & $28(18,7 \%)$ & $95(63,3 \%)$ & $27(18 \%)$ \\
- Decisional & $27(18 \%)$ & $94(62,7 \%)$ & $29(19,3 \%)$ \\
\hline
\end{tabular}

Uji validitas konstruk pada penelitian ini dilakukan dengan cara memodifikasi model pengukuran pada konstruk agresivitas dengan membebaskan beberapa kesalahan pengukuran untuk berkorelasi dengan item lainnya, sehingga diperoleh model fit dengan Chi-Squre $=322,83 d f=$ 289 P-Values $=0,08328 R M S E A=0,028$. Adapun uji validitas konstruk kontrol diri pada masing-masing aspek dapat dilihat pada tabel berikut ini:

Tabel 4

Model Fit Konstruk Kontrol Diri

\begin{tabular}{l|cccc}
\hline \multicolumn{1}{c}{ Aspek } & Chi-Square & $d f$ & $P$-Value & RMSEA \\
\hline Behavior & 7,01 & 4 & 0,13553 & 0,071 \\
Kognitif & 15,33 & 13 & 0,28695 & 0,035 \\
Decisional & 26,76 & 18 & 0,08358 & 0,057 \\
\hline
\end{tabular}

Uji regresi dilakukan pada penelitian ini untuk melihat keberpengaruhan kontrol diri terhadap agresivitas. Hasil uji koefisien regresi menunjukkan bahwa kontrol behavior dan decisional menghasilkan nilai signifikasi sesuai dengan teori. Adapun uji regresi pada kedua variabel dapat dilihat pada tabel di bawah ini: 


\section{Tabel 5}

Uji Koefisien Regresi dan Analisis Varian

\begin{tabular}{l|cccc}
\hline \multicolumn{1}{c}{ Model } & $B$ & $\begin{array}{c}\text { R Square } \\
\text { Change }\end{array}$ & Sig $(<0,05)$ & Ket \\
\hline Behavior & $-0,287$ & 0,084 & 0,020 & $8,4 \%$ \\
Kognitif & 0,062 & 0,000 & 0,620 & $0 \%$ \\
Decisional & $-0,242$ & 0,031 & 0,031 & $3,1 \%$ \\
\hline
\end{tabular}

Dependent variabel: Agresivitas

Tabel di atas menunjukkan bahwa pengaruh kontrol diri terhadap agresivitas sebesar 11,5\% dan masing-masing aspek memiliki arah yang negatif yaitu $-0,287$ dan $-0,242$. Artinya, secara pembuktian teori apabila individu memiliki skor yang tinggi pada kontrol behavior dan decisional, maka secara otomatis individu mampu untuk menurunkan tingkat kecenderungan berperilaku agresif terhadap orang lain. Sebaliknya, apabila individu tidak mampu mengendalikan behavior dan decisional nya atau dapat dikatakan memiliki skor yang rendah pada kedua aspek tersebut, maka perilaku agresif akan muncul meledak-ledak tidak terkontrol.

\section{Kesimpulan}

Hasil penelitian menunjukkan bahwa ada pengaruh kontrol diri secara bersamasama terhadap agresivitas. Secara spesifik, penelitian ini menemukan bahwa behavior control dan decisional control berpengaruh negatif secara signifikan terhadap agresivitas remaja. Variabel behavior control berarah negatif memberikan pengaruh yang signifikan terhadap agresivitas remaja. Artinya, semakin rendah skor aspek behavior control maka semakin tinggi agresivitas seseorang. Hal ini didukung oleh penelitian Dewall, dkk yang menyatakan bahwa self control dapat mencegah tindakan agresi. Menurutnya, kegagalan seseorang dalam pengendalian diri merupakan prediktor penting dari agresi terhadap orang lain. Semakin rendah kontrol perilaku (behavior control) seorang remaja, maka kecenderungan untuk bertindak agresif terhadap seseorang semakin tinggi. Dengan kontrol perilaku (behavior control) yang rendah, seseorang akan susah mengendalikan perilakunya untuk bertindak agresif baik itu terhadap diri sendiri maupun orang lain. Sebaliknya, jika seseorang memiliki kontrol perilaku yang tinggi, maka ia akan mudah mengendalikan perilakunya. Hasil penelitian ini juga menunjukkan bahwa decisional control berpengaruh signifikan dan berarah negatif. Artinya, semakin 
rendah skor aspek decisional control maka semakin tinggi agresivitas seseorang. Seseorang yang memiliki kontrol keputusan (decisional control) yang tinggi, cenderung lebih berhati-hati dan lebih bijak dalam bertindak. Sebaliknya, jika seseorang memiliki kontrol keputusan yang rendah, maka ia akan mudah bertindak ceroboh, bahkan salah dalam mengambil keputusannya dan akhirnya penimbulkan penyesalan dalam diri. Peneliti berasumsi bahwa siswa akan bertindak agresi ketika

\section{endnote}

${ }^{1}$ Kumparan. (2017). "Kasus Bullying Meningkat Pelakuk didominasi Remaja." Melalui <https://kumparan.com/@kumparanstyle/kasus -bullying-meningkat-pelaku-didominasi-olehremaja> [1/08/2017]

${ }^{1}$ Hartati, N., Nihayah, Z., Shaleh, A.R., Mujib, A. (2005). Islam dan Psikologi. Jakarta: RajaGrafindo Persada. Hal. 15-17

${ }^{1}$ Santrock, John. 1995. Life Span Development: edisi kelima. Jakarta : Erlangga. Hal. 103

${ }^{1}$ Hartati, N., Nihayah, Z., Shaleh, A.R., Mujib, A. (2005). Islam dan Psikologi. Jakarta: RajaGrafindo Persada. Hal. 18

${ }^{1}$ Hoaken, P.N.S., \& Stewart, S.H. ( 2003). Drugs of abuse and the elicitation of human aggressive behavior. Addictive Behaviors. 28. Hal. 1533-1554.

1 Taylor, S.E., Peplau, L.A., \& Sears, D.O. Social Psychology 12 th Edition. Psikologi sosial edisi kedua belas. Tri Wibowo B.S (terj). 2009. Jakarta: Kencana Prenada Media Group. Hal. 205

${ }^{1}$ Myers, D.G. (2009). Exploring Social Psychology 6 th. New York : The McGraw-Hall Companies. Hal. 118

${ }^{1}$ Gelles, R.J., Harrop, J.W., Vissing, Y.M., \& Straus, M.A. (1991). Verbal aggression by parents and mereka harus memilih keputusan apa yang akan mereka ambil, seperti mencemooh guru mereka karena diberi tugas yang banyak, atau mereka harus tetap mengerjakannya walaupun "terpaksa". Akan tetapi hasil penelitian menunjukkan bahwa siswa akan tetap mengerjakan tugas yang telah diberikan kepada mereka, karena mereka merasa lebih bermanfaat dari pada menghabiskan waktu untuk mencemooh guru.

psychosocial problems of children. Child Abuse and Neglect. 15. Hal. 223-238.

1 Fromm, E. The Anatomy of Human Destructiveness. Akar Kekerasan. Imam Muttaqin (terj). 2010. Yogyakarta: Pustaka Pelajar. Hal. 200

1 Buss, A.H., \& Perry, M. (1992). The Aggression Questionare. Journal of Personality and Social Psychology. 63 (3). Hal. 452-459.

1 McCullough, M.E., Willoughby, B.L.B. (2009). Religion, Self-Regulation, and Sel-Control: Associations, Explanations, and Implications. Psychological Bulletin. 135(1), 69-93.

1 Chaplin, J.P. Dictionary of Psychology. Kamus Lengkap Psikologi. Kartini Kartono (terj). 2008. Jakarta: Raja Grafindo Persada. Hal. 128

1 Tangney, J.P., Baumeister, R.F., \& Boone, A.L. (2004). High Self-Control Predict Good Adjustment, Less Pathology, Better Grades, and Interpersonal Success. Journal of Personality. 72(2). Hal. 271-282.

${ }^{1}$ Averill. J.R. (19730. Personal control over aversive stimuli and its relationship to stress. Psychology Bull. 80. Hal. 286-303.

1 Finkenauer, C., Engels, Rutger.C.M.E., \& Baumeister, R.F. (2005). Parenting behavior and adolescent behavioral and emotional problems: The role of self-control. International Journal of Behavioral Development. 29 (1), Hal. 58- 69. 
${ }^{1}$ DeWall, C.N., Finkel, E.J., \& Denson, T.F. (2011). Self-Control Inhibits Aggression. Social and
Personality Psychology Compass 5/7. Hal. 458-472. 10.1111/j.1751-9004.2011.00363.x. 
